\title{
Critical Success Factors for Sustainable Entrepreneurship in SMEs: Nigerian Perspective
}

\author{
Lawal, Fatai Alani
}

\author{
Department of Business Management, College of Business and Social Sciences, Covenant University \\ Ota, Nigeria; Emails: falawal@yahoo.com, fatai.lawal@stu.cu.edu.ng

\section{Dr. Worlu, Rowland E. (Associate Professor)}

Department of Business Management, College of Business and Social Sciences, Covenant University Ota Nigeria; rowland.worlu@covenantuniversity.edu.ng

\section{Ayoade, Omisade Ezekiel}

Department of Business Management, College of Business and Social Sciences, Covenant University Ota Nigeria; sadeayoade@yahoo.com, omisade.ayoade@stu.cu.edu.ng

\section{Doi:10.5901/mjss.2016.v7n3s1p338}

\begin{abstract}
Global developments now place emphasis on sustainability as an obvious goal and sustainable entrepreneurship has become a novel area of entrepreneurship providing the link between sustainability management, entrepreneurial activities and sustainable development. SMEs form major business establishments across different economies and in view of their numbers, they can play significant role in driving sustainable development and could also be effective in receptiveness to environmental and social problems. The participation of entrepreneurial firms in active sustainability disposition tend to tilt more towards large organisations and industries than Small and medium enterprises (SMEs). The focus of the study therefore is to $t$ establish factors that determine the extent to which SMEs can conduct business in a sustainable manner. The research utilized a descriptive method relying solely on review of secondary data and information in exploring theories underpinning entrepreneurship orientation and drivers of sustainable entrepreneurship behaviour among SMEs. Findings revealed that attitudinal, perceptual factors, firm size, sector, ownership, innovative orientation, personality, management skills, motivation, infrastructure, working capital management, and access to finance (amongst others) are critical to sustainable entrepreneurship among SMEs. The relativity of the observed critical factors to the ease of doing business in Nigeria by SMEs towards sustainable entrepreneurship was emphasised in the study. The study recommends the need for governmental agencies and educational establishments to provide adequate information and enlightenment to foster sustainable entrepreneurship among SMEs.
\end{abstract}

Keywords: Sustainable Entrepreneurship, Development, Sustainability, and SMEs.

\section{Introduction}

Research on sustainable entrepreneurship has attracted wide interest in recent years following global developments that emphasis sustainability in addressing environmental and social issues. The concept of entrepreneurship has existed for ages and is considered as the essence of enterprise (Majid and Koe, 2012). It is centred on the identification, evaluation and exploitation of opportunities (Shane and Venkataraman, 2000). SME and entrepreneurship are often used interchangeably, but differ from each other in that entrepreneurship is a process that leads to the creation of SMEs and business endeavours, whereas SMEs are simply business ventures arising from entrepreneurial pursuits of individuals and is managed by individuals or owner-managers (Esuh, 2012). The extent to which entrepreneurs and managers are able to display their innate potentials, ingenuity, and dynamism goes a long way in determining wealth creation possibilities in an economy and the degree of competitiveness of its firms. Through entrepreneurial innovations, business opportunities are detected and resources are deployed towards translating the idea generated into viable business ventures in form of SMEs. According to Grahams (2010), the emergence of the concept of sustainable entrepreneurship has changed the ways people perceived business activities and their impacts on environment.

Sustainable entrepreneurship is an off-shoot of Sustainable development and it is a noticeable development these days for organisations to brand themselves as sustainable entrepreneurs. Indeed, researchers have suggested the 
integration of sustainability management and business practices among entrepreneurs to contribute to sustainable development (Tilley \& Young, 2009; Parrish, 2010). Crals and Vereek (2004) viewed sustainable entrepreneurship from the perspective of sustainable development which is principally concerned with the triple bottom line (people, planet and profit). The first $P$ (people) relates to the behaviour of firms in terms of social and ethical dimension, treatment of employees and promotion of social cohesion - human right protection and gender relationship. The second $\mathrm{P}$ (planet) summarises disposition of the firm towards the environment while the third $\mathrm{P}$ (profit) relates with the financial returns of an enterprise, allocation and distribution of gains between relevant stakeholders. They further opined that the sustainability of entrepreneurial activity is consistent with satisfying and maintaining balance amongst the components off the triple bottom line.

SMEs and entrepreneurial development have been widely acclaimed as the tools for achieving economic growth and development in view of the contributions of SMEs to employment generation and gross domestic products (GDP) and have consequently attracted the focus of nations in the bid for national development (Dalberg, 2011; Koe, Omar, and Sa'ari, 2015). In spite of the growing interest in the field of sustainable entrepreneurship, most of the extant empirical literatures sees sustainable entrepreneurship as a business strategy mostly adopted by large corporations and industrial companies rather than SMEs (Fuller and Tian, 2006; Jenkins, 2006; Perrini, Russo and Tencati, 2007). The objective of this study is therefore to explore whether and to what extent SMEs can accommodate the conduct of businesses in a sustainable manner with a view to identifying determinants of success while extrapolating this to the ease of doing business within the Nigerian context. Relevant research questions for consideration in this study are:

- What are the indicators of sustainable entrepreneurship?

- Why are large organisation often perceived as being sustainable entrepreneurs?

- What are the limiting factors that determine the extent to which SMEs can be responsive to demands of sustainable entrepreneurship

\section{Review of Related Literature}

\subsection{Entrepreneur and Entrepreneurship}

Entrepreneurship as a subject of research has been widely studied in the literature of management and economics. Vincent (nd) established that entrepreneurship relates to economic demand recognition in an economy and supply of factors of production with a view to fulfilling that demand and ultimately generating profit. Motomura (nd) sees anyone capable of generating results in any area of human activity as an entrepreneur, and people having power to make things happen are Entrepreneurs. Batra (2012) relates entrepreneurship and enterprise creation to looking for new products or combinations with a view to satisfying needs, effective organisation of resources and achieving wealth creation and value addition by way of employment generation.

Cuervo, Ribeiro and Roig (cited in Reynolds, 2005) opined that the concept of entrepreneurship encompasses entrepreneurial function which is an embodiment of opportunities discovery, risk bearing and subsequently creating new economic activity. Their views is also in consonance with those of Eckhardt and Shane (2003) who extended entrepreneurial function to include identification, assessment and exploitation of opportunities with the development of appropriate strategy and optimisation of resources. Reynolds (2005) conceptualised the entrepreneurial function as unearthing of opportunities and consequently, conception of new economic activities through establishment of new organisations. From the perspective of Eckhardt and Shane (2003), entrepreneurship as a business process encompasses identification and appraisal of opportunities, the choice to exploit or sell them, efforts to acquire resources, the development of appropriate strategy, and the design of the new project.

Schumpeter (1989, cited in Bula, 2012) viewed entrepreneurship from the perspective of innovation and creative destruction. In such situations, the entrepreneur derives pleasure in being a social leader whose primary preoccupation is to provide service to the society without necessarily having economic profit undertone. Thus, by transforming the economic system from static equilibrium position to situation where new products are created or devising new production methods, entrepreneurs are seen as constituting a driving force towards economic development. Schumpeter's perception of entrepreneurship is closely linked with innovation instead of imitation. Schumpeter's innovation dimension viewed entrepreneur as an economic and social forerunner who derives satisfaction in being an innovator and service provider to the society without necessarily capitalising on economic profit. Thus, moving the economy out of static equilibrium position is the underlining principle of the Schumpeter theory.

Entrepreneurship is critical to enhancing the innovativeness and responsiveness of businesses, boosting productivity and to improve cost structures and trade performance. Harper (2003) emphasised that the entrepreneurial 
spirit may manifest itself in the development of new markets, new products, new methods of production and management, the discovery of new inputs and the establishment of new businesses and even new organisational forms.

\subsection{Sustainable Entrepreneurship and Sustainable Development}

Sustainable entrepreneurship is a new concept that links sustainable development with business activities (Schaltegger \& Wagner, 2008). There is no universally accepted definition of sustainable entrepreneurship as researchers have suggested various definitions over the years. Some researchers called it "sustainability-driven entrepreneurship" (Majid, Kamaludin, Saad \& Aziz, 2012) or "sustainable-minded entrepreneurship" (Gagnon, 2012). Some studies have also simply equated it to "environmental entrepreneurship" (Krueger, 2005; Schlange, 2006). Crals and Vereeck (2004) defined sustainable entrepreneurship "as the continuing commitment by businesses to behave ethically and contribute to economic development while improving the quality of life of the workforce, their families, the local and global community as well as future generations". Therefore, Sustainable entrepreneurs are those enterprises that support sustainable development by ensuring that businesses are done in a sustainable fashion. However, Motomura (nd) posited that sustainable entrepreneurship involves ensuring that things happen in a manner that takes cognisance of short, medium and long-term consequences.

Sustainable entrepreneurship is in harmony with entrepreneurs striving for profit as well as improving local, global, environmental and social conditions. Crals and Vereeck emphasised that a fundamental canon of sustainable entrepreneurship involves businesses inculcating the consciousness to continually demonstrate ethical behaviour and contribute to economic development while simultaneously ushering an era of improvement in overall well-being of employees, their families, and the society at large. They further identified environmental audits, social audits, labels, and corporate code of conduct (amongst others) as essential instruments being deployed towards assessing sustainable entrepreneurship. From the economic perspective, WCED report (1987, cited in Bossel, 1997) viewed sustainable development as economic development that meets the needs of the present without compromising the ability of future generations to meet their own needs. In essence, sustainable development is equitable and balanced and in other for development to continue indefinitely, it should consider balancing the interests of groups of people across generations simultaneously in three major distinct areas: social, environmental and economic Business sustainability therefore measures the potential of businesses to withstand and survive shocks that is characteristic of intimate connection of the business to healthy economic, social and environmental systems. Thus, to attain business sustainability, entrepreneurs need to effectively manage financial and environmental risks, as well as obligations and opportunities.

One of the significant shifts in recent time is that sustainable entrepreneurship is slowly moving from merely fulfilling economic needs in its initial stage to incorporating sustainability practices in the latter stage. Majid and Koe (2012) posited that the works of the previous researchers (such as Crals and Vereeck, 2004; Tiley and Young, 2009) based on Triple Bottom Line concept (economic prosperity, environmental quality, and social justice) does not include cultural domain. Hence, Majid and Koe proposed a new model of sustainable entrepreneurship that incorporates economic, social, ecological (environmental), and cultural domains.

Brand and Dam (2009) stressed the distinction between corporate social responsibility exhibited by firms in the tangible product sector (manufacturing) and intangible service industry and established positive relationship between the degree of tangibility and environmental friendly behaviour. Perrini et al corroborates the findings that firms producing tangible goods are often engaged in environmental management activities than firms in other sectors. This is because more raw materials and waste are generated and more potential for pollution in the production process in the tangible product sector than intangible services sectors, thus necessitating the need for firms in the tangible product sector to behave in a sustainable manner.

\subsection{Theoretical underpinnings of entrepreneurship}

Various theories have been put forward by scholars to explain the field of entrepreneurship. Theories such as Economic entrepreneurship, Psychological entrepreneurship, Sociological entrepreneurship, Anthropological entrepreneurship, Opportunity-Based entrepreneurship, and Resource-Based entrepreneurship have their roots in economics, psychology, sociology, anthropology, and management (Kwabena, 2011).

\subsubsection{Economic Entrepreneurship theories}

The economic entrepreneurship theories explore the economic factors that enhance entrepreneurial behaviour and it is 
deeply rooted in the classical and neo-classical theories of economics, and the Austrian market process (AMP)

\subsubsection{Classical Theory}

The classical theory eulogized the benefit of free trade, specialization, and competition. The theory highlights the directing role of the entrepreneur in the context of production and distribution of goods in a competitive marketplace. This theory has been faulted by Murphy, Liao \& Welsch (2006) for its failure to account for the dynamic upheaval generated by entrepreneurs of the industrial age.

\subsubsection{Non-Classical Theory}

The neo-classical model is an off-shot of the criticisms of the classical model and pointed out that economic phenomena could be relegated to instances of pure exchange, reflect an optimal ratio, and transpire in an economic system that was basically closed. The economic system consisted of exchange participants, exchange occurrences, and the impact of results of the exchange on other market actors. Murphy, Liao and Welsch (2006) emphasize the importance of exchange in addition to diminishing marginal utility which create enough motivation for entrepreneurship in the neoclassical movement.

\subsubsection{The Austrian Market Process (AMP)}

In the AMP model, Schumpeter (1934) focused on human action in the context of an economy of knowledge and describes entrepreneurship as a driver of market-based systems where an important function of an enterprise was to create something new which resulted in processes that served as impulses for the motion of market economy.

\subsubsection{Psychological entrepreneurship theories.}

According to Landstrom (1998), psychological theories emphasize personal characteristics of individuals that under-pines entrepreneurship. In addition to personality traits, need for achievement and locus of control, ability to take risk, innovativeness, and tolerance for ambiguity are found as being associated with entrepreneurial inclination.

\subsubsection{Personality Traits Theory}

Personality traits are steady attributes that an individual exhibits in most circumstances (Coon, 2004). Personality traits are seen as enduring inborn qualities or potentials of the individual that naturally make him an entrepreneur. Some of the characteristics or behaviours associated with entrepreneurs as highlighted by Coon (2004) are: tendency towards being more opportunity driven, demonstration of high level of creativity and innovation, display of high level of management skills and business know-how, optimism, emotional resilience and mental energy, hard working spirit, intense commitment and perseverance, competitive desire to excel and win, tendency to be dissatisfied with the status quo and desire for improvement, transformational in nature, lifelong learners and often use failure as a tool and springboard.

\subsubsection{Need for Achievement Theory}

According to McClelland (1961), entrepreneurs are propelled by penchant for achievement and the desire for excellence and accomplishment. Mohar, Singh and Kishore (2007) emphasises that attributes such as affinity to take risk and proactiveness in being innovative as well as accommodation for ambiguity significantly influences entrepreneurial inclination.

\subsubsection{Sociological entrepreneurship theory}

Sociological enterprise focuses on the social context. Reynolds (1991) looks at entrepreneurship from social perspective and further identified four social contexts that relate to entrepreneurial opportunity vis-a-vis:

- building social relationships and bonds that fosters trust instead of opportunism,

- ethnic identification where individual's sociological background serve as decisive factor in propelling entrepreneurial affinity,

- population ecology (in which case environmental factors) determine survival of new ventures and 
- life course stage context which involves analyzing life situations and characteristic of individuals who have decided to become entrepreneurs.

\subsubsection{Anthropological entrepreneurship theory}

This theory is based on the premise that social and cultural context needs to be considered as a precursor to successful initiation of a venture, in which case, cultural practices leads to innovation and subsequent venture creation attitude.

\subsubsection{Opportunity-based entrepreneurship theory}

An opportunity-based approach provides a wide-ranging conceptual framework for entrepreneurship research (Shane, 2000). Entrepreneurs does not necessarily bring about change but utilise the opportunities that change (in technology, consumer preferences etc.) creates. Consequently, the entrepreneur always search for change, responds to it, and exploits it as an opportunity.

\subsubsection{Resource-based entrepreneurship theory}

Resource- based theory of entrepreneurship is anchored on the premise that access to resources has been identified as the predictor of entrepreneurial opportunity (Alvarez and Busenitz, 2001). The importance of access to financial, social and human resources in enhancing ability of individuals to detect and act upon opportunities discovered cannot be overemphasized (Davidson and Honing, 2003).

\subsection{Determinants of sustainable entrepreneurship}

\subsubsection{Attitudinal and Perceptual factors}

Koe, Omar and Sa'ari (2015) revealed that attitudinal factor (i.e. sustainable attitude) and perceptual factors (i.e. perceived desirability and perceived feasibility) were important in influencing a person's level of propensity to sustainable entrepreneurship. Whereas, the research only examined the direct influences of attitudinal, normative and perceptual factors on propensity to sustainable entrepreneurship, behavioural intention or propensity is a complex process which could take place through several stages. This pre-supposes the need for future researchers to expand the research framework by integrating mediating or moderating factors. Cambra-Fierro, Hart and Polo-Redondo (2008) proposed variables relevant to sustainable entrepreneurship to include: legal context, management's personal values, socio-cultural context, market forces, ownership management structure, and industry- sector characteristics.

\subsubsection{Firm Sector, Size, Ownership, and Innovative Orientation}

The sector a firm belong, the size of the firm, ownership structure, and degree of innovative orientation determines the extent to which sustainable entrepreneurship behaviour is exhibited. Uhlaner, Brent and Jeurisse (2010) opined that larger firms, firms from more tangible products sectors, family owned firms, and firms with a more innovative orientation have more inclination towards manifesting sustainable entrepreneurship behaviours. This is without prejudice to other dimensions of sustainable entrepreneurship such as employees (individuals in the firm), suppliers and clients (direct stakeholders) and the larger society. These views are in consonance with the resource-based view of large firms, which perceive large firms as having more manpower and financial stability (Lepoutre and Heene, 2006). Large firms are more exposed to the public, and any attempt to exhibit irresponsible behaviours will undermine their survival and reputation. Responsiveness of family firms towards community related developmental activities and avoidance of actions that are detrimental to peaceful co-existence (e.g. polluting the environment) is a direct consequence of closeness to the local community and willingness to share their prosperity (Uhlaner, Goor-Balk and Masurel, 2004; Dyer and Whetten, 2006).

\subsubsection{Personality, Management skills, Environmental and Motivation factors}

The key performance indices and extent of growth of an organisation are measures of business success. Triggering factors (for example personality and motivation) that propels entrepreneurs into wearing thinking cap on one hand and enhancing factors (such as management skills, and education level -formal and informal) on the other hand are crucial to 
entrepreneurial success (Dionco-Adetayo, 2004). Thus, Dionco-Adetayo established that there is significant positive relationship between motivating factors, personality characteristics, management skills and abilities, level of education, environmental forces, and entrepreneurial success. Naqvi (2011) emphasised customer services expertise and past experience of the manager as being vital to entrepreneurial sustainability and success.

\subsubsection{Targeted Government Support and other forms of Support}

Government targeted support towards SMEs is effective in ushering in growth and development of the sector (Maseko et al, 2012). Support in the area of research, quality assurance, marketing, financial management and technology are needed to transform SMEs operations into viable businesses that can compete in the global market place. Rahman and Singh (2014) established existence of significant relationship between entrepreneurial success and entrepreneurial level of support typified by family support, friend circle / peer group support, government support for subsidy and supply of raw materials, selling of products, provision of technology and quality testing.

\subsubsection{Challenges of infrastructure, finance, economic and environmental factors}

Sustainable Entrepreneurship, a responsive ethical commitment towards overall well-being of local, global environment and social conditions is dependent on infrastructure adequacy and sufficiency. Its adequacy and efficiency is crucial because of the over-bearing consequence on the growth and development of other economic activities. Fedderke and Garlic (2008) made two broad classification of infrastructure vis-a-vis economic infrastructure (transport, communications, power generation, water supply and sanitation facilities) and social infrastructure including educational and health-care facilities. Tachiwou (2011) stressed that a fast growing economy is dependent on faster development of infrastructure. The kind of activities that can be embarked upon and the type of sector that can develop in an economy is dependent on an extensive and efficient infrastructure. Where there is widespread infrastructure network, it goes a long way in reducing income inequality, alleviating poverty, as well as lead to improved economic growth.

In another development, Rahman and Singh (2014) identify other factors that are significantly associated with the level of success of the entrepreneurs as: power supply, access to latest technology, competitive pricing, access to market channels, and access to business associations with uninterrupted power supply and access to latest technology being very crucial for achieving success in manufacturing MSME (micro, small and medium enterprises) in general.

\subsection{SMEs and challenges of doing business in Nigeria}

Globally, Nigeria ranked low in the quality of its infrastructure which impacts the ease of doing business. According to World Economic Forum Global Competitiveness Report (2014) involving a survey on competitiveness performance of 144 economies worldwide, Nigeria ranked $133^{\text {rd }}$ in the quality of overall infrastructural development. Inadequate supply of infrastructure clearly emerged as the most challenging factor for doing business in Nigeria. Subsequently, corruption and access to finance follows respectively. The elements of the competitiveness report categorised into 12 distinctive features include infrastructure, institutions, financial market development, goods market efficiency, macroeconomic environment, labour market efficiency, health and primary education, higher education and training, technological readiness, labour market efficiency, business sophistication, market size, and innovation of existing policies. There is no gainsaying the fact that there is pressure on firms to plunge enormous capital to provide alternate infrastructural facilities to progress their businesses, thus, forcing organisations to carry high cost component which reduces efficiency and results in diminishing competitiveness for their products. It is therefore obvious that the tendency for SMEs to exhibit sustainable entrepreneurship endeavour and practice will be hampered.

Table 1: Comparison of Competitive Ranking

\begin{tabular}{|l|c|c|c|}
\hline Criteria & 2014-15 Ranking/ 134 & 2013-14 Ranking/ 135 & 2012-13 Ranking/127 \\
\hline Quality of Overall infrastructure & 133 & 129 & 117 \\
\hline Quality of roads & 125 & 127 & 114 \\
\hline Quality of railroad infrastructure & 100 & 101 & 95 \\
\hline Quality of port infrastructure & 110 & 112 & 106 \\
\hline Quality of air transport infrastructure & 121 & 108 & 100 \\
\hline Quality of Electricity supply & 141 & 141 & 138 \\
\hline
\end{tabular}




\begin{tabular}{|l|l|l|l|}
\hline Mobile telephone subscription/100pop. & 116 & 124 & 124 \\
\hline Fixed telephone subscription/100pop & 142 & 145 & 135 \\
\hline Country Ranking on Global Competitiveness Index & 134 & 135 & 127 \\
\hline & & & \\
\hline
\end{tabular}

Source: Adopted from World Economic forum: Global Competitiveness Reports: 2014-2015; 2013- 2014, and 2012-13.

Menace of infrastructure could take either general or specific dimension. Igwe, Oyelola, Ajiboshun, and Raheeml (2013) identified general and specific infrastructure challenges to include the following:

- major financing of infrastructure projects resting squarely on federal government.

- Insufficiency of annual budget allocations to meet demand for infrastructure in the economy.

- Procedure for allocating budget and contracting to rehabilitate existing infrastructure and execution of new projects is often prone with corrupt practices.

- Prevalence of capacity gaps for project development, operations, management, and maintenance.

\subsubsection{Menace of Finance}

Availability of finance is critical to the development of SMEs (Atieno, 2001). Despite wide acclaimed role of SMEs in promoting growth, innovation and prosperity of developing economies, access to and available of needed capital to achieve growth and expansion is a major constraint encountered by SMEs. This is without undermining the importance of targeted government assistance in starting, growing and expanding SMEs business operations (Herbert, 2008). According to Dalberg (2011), the inability of SMEs to access finance from local banks is attributed to the following debtfinancing barriers:

- High risk profiling of SME market and challenge in satisfying collateral requirements.

- Preference of banks for earning higher returns on traditional lending activities.

- Prevalence of high administrative cost on lending to SMEs.

- Inability of banks to provide long-term capital due to significant short-term liabilities in their deposit mix.

- Occasional paucity of information, lack of adequate skills, and regulatory support to embark on SME lending.

According to Sunday (2011), the survival of SMEs in Nigeria is predicated upon appropriate standard credit policy, effective management of working capital (which goes a long way in guaranteeing continuity, growth and solvency), and as well articulated financial report and control system.

\section{Conclusion, Policy Implications and Recommendations}

Sustainable entrepreneurship is an offshoot concept from sustainable development that encompasses new dimensions in business such as stakeholder participation, ecological care, ethical entrepreneurship, and corporate social responsibility. Sustainable entrepreneurship practise is not an exclusive domain of large firms although the concept is rather new and gradually rearing its head for relevance amongst small and medium enterprises. The propensity of SMEs to pursue sustainable entrepreneurial behaviour is dependent on factors including: attitudinal and perceptual, firm size, sector, ownership, innovative orientation, personality, management skills, motivation, infrastructure, working capital management, and access to finance amongst others.

To develop more sustainable enterprises, governmental agencies and educational establishments should provide adequate information and enlightenment on the need for sustainable entrepreneurship among SMEs. This is with a view to equipping them with adequate knowledge and awareness to pursue sustainable entrepreneurial business practice that on the long run elicits positive organisational reputation, motivation of employees, risk control, market preference and opportunities, and improvement in internal business dynamics.

\section{References}

Alvarez, S., \& Busenitz, L. (2001), "The entrepreneurship of resource based theory", Journal of Management, 27.

Atieno, R. (2001). Formal and informal institutions' lending policies and access to credit by small-scale enterprises in Kenya: An empirical assessment, Paper111, African Economic Research Consortium, Nairob.

Batra, S. (2012).Sustainable Entrepreneurship and Knowledge Based Development. $11^{\text {th }}$ International Entrepreneurship Forum Kaula Lumpur, Malaysia. http://www.essex.ac.uk/1-sustainable entrepreneurship (accessed 27.10.15) 
Brand, M.J., \& Dam, L. (2009), "Corporate Social Responsibility in Small Firms - Illusion or Big Business? Empirical Evidence from the Netherlands", RENT Conference, Budapest, Hungary. Retrieved from www.academia.edu on 15/7/15.

Bula, H. O. (2012). Evolution and Theories of Entrepreneurship: A critical review of the Kenyan perspective. International Journal of Business and Commerce 1(1), 81-96.

Cambra-Fierro, J., Hart, S., \& Polo-Redondo, Y. (2008). Environmental Respect: Ethics or Simply Business? A Study in the Small and Medium (SME) Context. Journal of Business Ethics, 82, 645-656.

Coon, D. (2004). Introduction to Psychology (9th Ed) Minneapolis: West Publishing Company.

Crals, E., \& Vereeck, L. (2004). Sustainable Entrepreneurship in SMEs: Theory and Practice. www.persons.org.uk/ptb/ejgc/ejgc3/crals vereeck. (accessed On 17.10.15)

Dalberg (2011). Report on support to SMEs in developing countries through financial intermediaries. www.eib.org/attachments/delberg_ sme-briefing accessed on 22.11.15.

Davidson, P., \& Honing, B. (2003), "The role of social and human capital among nascent entrepreneurs", Journal of Business Venturing, $20,121$.

Dionco-Adetayo, E. A. (2004). Determinants of Small firms' Entrepreneurial success In a developing economy. www.sbaer.uca.edu/ research accessed 10.11.15.

Drucker, P.F. (1985). Innovation and Entrepreneurship. New York: Harper \& Row Publishers.

Dyer, W.G., \& Whetten, D. A. (2006), "Family Firms and Social responsibility" preliminary Evidence from the S\&P 500", Entrepreneurship: Theory \& Practice, 30, 785-802.

Eckhardt, J.T. \& Shane, S.A. (2003). Opportunities and entrepreneurship. Journal of Management, 29, 333-349

Esuh, O.L. (2012). Is small and medium enterprise (SME) an entrepreneur?. International Journal of Academic Research in Business and Social Science, 2 (1).

Fedderke, J., \& Garlic, R. (2008). Infrastructural development and Economic growth In South Africa: A review of accumulated evidences. Policy Number 12. www.econrsa.org (accessed on 26.10.15).

Fuller, T., \& Tian, Y. (2006), "Social and Symbolic Capital and Responsible Entrepreneurship: An Empirical Investigation of SME Narratives", Journal of Business Ethics, 67, 287-304

Gagnon, M.A. (2012). Sustainable Minded Entrepreneurs: Developing and Testing a Value-based Framework. Journal of Strategic Innovation and Sustainability, 8(1), 9-25.

Graham, S. (2010). What is Sustainable Entrepreneurship? Accessed on 5.11 .15 from http://biznik.com/articles/what-is-sustainable entrepreneurship.

Harper, D.A. (2003). Foundations of Entrepreneurship and Economic development. New York. Routledge.

Herbert, R. (2008). Challenges of structuring a productive investment climate: The policy framework for investment and SME development. Official document of NEPAD-OECD Africa Investment Initiative. Accessed on 10.10 .15 from www.oecd.org/ investment.

Igwe, C.N., Oyelola, O. T., Ajiboshun, I. O., \& Raheem, S. (2013). A review: Nigeria's Transportation System and the Place of Entrepreneurs. Journal of Sustainable Development Studies, 3(2).

Jenkins, H. (2006), "Small Business Champions for Corporate Social Responsibility", Journal of Business Ethics, 67, 241-256

Koe, W., Omar, R., \& Sa'ari, J.R. (2015). Factors Influencing Propensity to Sustainable Entrepreneurship of SMEs in Malaysia. Procedia - Social and Behavioral Sciences, 172. Accessed at www.sciencedirect.com

Krueger, N.F. (2005). Sustainable Entrepreneurship: Broadening the Definition of Opportunity. 19th National Conference of United States Association for Small Business and Entrepreneurship (USASBE), California, USA.

Kwabena, N. S. (2011). Entrepreneurship theories and Empirical research: A Summary Review of the Literature. European Journal of Business and Management, 3 (6).

Lepoutre, J., \& Heene, A. (2006), "Investigating the Impact of Firm Size on Small Business Social Responsibility: A Critical Review", Journal of Business Ethics, 67, 257-273.

Majid, I.A., Kamaludin, M.H., Saad, M.S.M., \& Aziz, N.A. (2012). Sustainability-driven Entrepreneurship: The Mediating Effect of Opportunity based Management Structure on the Relationship between Entrepreneurial Orientation and Environmental Sustainability Management of SMEs: A Conceptual Framework. European Journal of Business and Management, 4(13), 148155.

Maseko, N., Manyan, I. O., Chiriseri, L., Tsekea, S., Mugogo, P. C., Chazuza, T., \& Mutengezanwa, M. (2012). An analysis of the impact of targeted government support on SMEs growth and development in Zimbabwe: a survey of Mashonaland Central Province. Journal of Research in International Business Management 2(2) ,51-59.

McClelland, D.C. (1961). The Achieving Society, NJ: Van Nostrand, Princeton

Motomura, O. (nd). Sustainable Entrepreneurship. http://www.paricenter.com/library/Papers/sustainable_repreneurship.pdf. (accessed 20.1.15).

Mohar, Y .M.S., Singh, J., \& Kishore, K. (2007), Relationship Between psychological characteristics and entrepreneurial inclination: A Case Study of Students at University Tun Abdul Razak, Journal of Asia Entrepreneurship and Sustainability.

Murphy, J.P., Liao, J., \& Welsch, P.H. (2006). "A Conceptual history of entrepreneurial thought". Journal of Management History. 12, 924.

Naqvi, S. W. H. (2011). Critical Success and Failure factors of Entrepreneurial Organisations: Study of SMEs in Bahawalpur. Journal of Public Administration and Governance, 1(2). 
Perrini, F., Russo, A., \& Tencati, A. (2007), "CSR Strategies of SMEs and Large Firms. Evidence from Italy", Journal of Business Ethics $74,285-300$.

Parrish, B. D. (2008). Sustainability-Driven Entrepreneurship: A literature review. Accessed at www.see.leeds.ac.uk on 20/06/15.

Parrish, B.D. (2010). Sustainability-Driven Entrepreneurship: Principles of Organization Design. Journal of Business Venturing, 25(5), 510-523.

Rahman H.,\& Singh H. R. (2014). Entrepreneurial Support and its levels of Success. Global Journal for Research Analysis, 3(11).

Rahman, H., \& Singh, H. R. (2014). Economic and Environmental factors leading to Entrepreneurial success. Indian Journal of Applied Research, 4(12).

Reynolds, P.D. (2005).Understanding business creation: Serendipity and scope in two decades of business creation studies. Small Business Economics, 24, 359-364.

Reynolds, P.D. (1991), "Sociology and entrepreneurship: concepts and contributions", Entrepreneurship: Theory \& Practice, 16(2), 4770.

Schaltegger, S., \& Wagner, T. (2008). Types of Sustainable Entrepreneurship and Conditions for Sustainability Innovation: From the Administration of a Technical Challenge to the Management of an Entrepreneurial Opportunity. In R. Wüstenhagen, J. Hamschmidt, S. Sharma,\& M. Starik (Eds.). Sustainable Innovation and Entrepreneurship (pp. 27-48). Glos: Edward-Elgar.

Schlange, L.E. (2006). What Drives Sustainable Entrepreneurs? 3rd Applied Business and Entrepreneurship Association International (ABEAI) Conference, Kona, Hawaii.

Shane, S.A (1994), "The Effect of National Culture on the Choice between Licensing and Direct Foreign Investment", Strategic Management Journal 15,627-642

Shane, S., \& Venkataraman, S. (2000). The promise of entrepreneurship as a field of research. Acad. Manag. Rev, 25, 217-226

Spence, L. J., \& Schmidpeter, R. (2003). SMEs, Social Capital and the Common Good, Journal of Business Ethics, 45, 93-108

Sunday, K. J. (2011). Effective Working Capital Management in Small and Medium Scale Enterprises (SMEs). International Journal of Business and Management, 6(9).

Tachinou, A. M. (2011).Infrastructural development and Economic Growth in Togo. International Journal of Economics and Finance, 3 (3).

Tilley, F., \& Young, W. (2009). Sustainability Entrepreneurs: Could They Be the True Wealth Generators of the Future? Green Management International, 55, 79-92.

Uhlaner, L.M., Goor-Balk, H. J. M., \& Masurel, E. (2004), "Family Business and Corporate Social Responsibility in a Sample of Dutch Firms", Journal of Small Business and Enterprise Development, 11, 186-194.

Uhlanar, L. M., Berent, M. M., \& Jeurissen, R. J. M. (2010). Family Ownership, Innovation and other context variables as determinants of sustainable Entrepreneurship in SMEs: An empirical research study. Available at www.researchgate.net.

Vincent, G. (nd). Sustainable Entrepreneurship: The role of Microfinance, Entrepre-neurship and Sustainability in Reducing Poverty in Developing Countries. www.gdrc.org/icm/micro/guy_sust-micro.pdf (accessed 17.1.16)

World Economic Forum. Global Competitivess Report (2014-15, 2013-14, 2012-11) www3.wefrom.org/docs/wef_global competitiveness report accessed 19.1.16. 